\title{
Temporal variations of sediment source from a reservoir catchment in the black soil region, Northeast China
}

\author{
Fang Haiyan* \\ Key Laboratory of Water Cycle and Related Land Surface Processes, Institute of Geographic Sciences and Natural Resources Research, Chinese Academy of \\ Sciences, Beijing 100101, China
}

\section{A R T I C L E I N F O}

\section{Article history:}

Received 2 November 2014

Received in revised form 17 April 2015

Accepted 28 April 2015

\section{Keywords:}

Temporal variation

Sediment source

Catchment

Sediment deposit

Radionuclides

Black soil region

\begin{abstract}
A B S T R A C T
An understanding of long term temporal variations in sediment sources from a catchment is necessary to identify the major sources of sediment for effectively implementing soil conservation measures. For this purpose, a sediment column from Qixin reservoir and 410 samples from the three potential sediment sources were collected and radionuclides, soil organic carbon (SOC) and soil texture were analyzed. The relative contributions from different sources were determined using a simple mixing model with ${ }^{137} \mathrm{Cs}$ and ${ }^{210} \mathrm{~Pb}_{\mathrm{ex}}$. The mean contribution of sediment from cultivated lands to the sediment deposit was $50.87 \%$, varying from $12.22 \%$ to $80.84 \%$. Uncultivated lands contributed a mean of $5.22 \%$ ranging from $0.01 \%$ to $21.49 \%$ and gully/channel banks contributed $43.91 \%$ ranging from $15.15 \%$ to $86.91 \%$. The relative contributions from the cultivated and uncultivated sediment sources to the reservoir deposit were significantly $(P=0.01)$ correlated with radioactivities, SOC and $\mathrm{D}_{50}$. The temporal variations of sediment source were determined by yearly rainfall amount and rainfall erosivity. The results indicate that conservation practices should be prioritized in the cultivated lands and gullies/channels and temporal preparation strategies for heavy rainstorms should be considered using physical soil erosion models combined with field investigation.
\end{abstract}

(c) 2015 Elsevier B.V. All rights reserved.

\section{Introduction}

Sediment source is essential in establishing a catchment sediment budget, developing models, and designing and implementing soil conservation strategies (Gruszowski et al., 2003; Haddadchi et al., 2014). Thus, interest in sediment source identified by fingerprinting properties has increased in recent decades, and more and more work on sediment sources have been conducted in many regions over the world, such as in the UK (Gruszowski et al., 2003), the USA (Wallbrink et al., 1998; Lamba et al., 2015), Brazil (Franz et al., 2014), Tunisia (Slimane et al., 2013), Korea (Kim et al., 2013) and Chinese Loess Plateau (Zhang et al., 1989; Yang and Xu, 2010) and Southwestern region (Zhang et al., 2004). However, seldom study on this issue has been conducted in the black soil region of Northeastern China, where soil has been experiencing severe erosion, resulting from the easy erodibility of black soil, harsh climatic conditions and extensive human activity.

Fingerprinting technique used to identify sediment sources is based on linking the physical or geochemical properties of the potential sediment sources to sediment at the catchment outlet

\footnotetext{
* Tel.: +86010 64889036 .

E-mail address: fanghy@igsnrr.ac.cn (F. Haiyan).
}

(Haddadchi et al., 2013; Lamba et al., 2015). Different types of fingerprinting properties such as metals (e.g., Blake et al., 2012), stable isotopes (e.g., McKinley et al., 2013), mineral magnetic properties (Walling et al., 1999) and fallout radionuclides (e.g., Huisman et al., 2013) have been used, among which fallout radionuclides ${ }^{137} \mathrm{Cs}$ and ${ }^{210} \mathrm{~Pb}_{\text {ex }}$ are commonly used in a variety of geomorphic settings (e.g., Peart and Walling, 1986; Wallbrink et al., 1998; Gruszowski et al., 2003).

Sediment sources and sinks are highly variable in time. The climate changes may result in temporal changes of precipitation, temperature and land cover, which may induce different erosion and sediment transport processes (Kim et al., 2013). For example, due to changing discharge and suspended sediment, the sediment contributions from surface/subsurface were different during a flood event (Yang and Xu, 2010; Gourdin et al., 2014). Monthly changes of sediment contributions from woodland, channel bank, pasture and cultivated lands were also observed by Walling (2005). Seasonally, bare soils on upland area in spring are more prone to erosion, while stream banks are easily eroded in winter during freeze-thaw activity (Gellis and Noe, 2013). Similarly, catchment sediment output also changes throughout a year. Accumulated sediment in reservoirs contains long term erosion information and has been used worldwide to study variations of sediment yield 
(Nahm et al., 2010; Lamba et al., 2015). However, few work were conducted with sedimentation information to identify long term changes of sediment source.

Therefore, the aim of this study is to analyze the annual dynamics of potential sediment sources with radionuclides properties using the sedimentation information from Qixin reservoir in the typical black soil region, Northeastern China.

\section{Materials and method}

\subsection{Study area}

The $9.9 \mathrm{~km}^{2}$ reservoir-controlled Qixin catchment $\left(\mathrm{E} 106^{\circ} 21^{\prime}\right.$, $\mathrm{N} 47^{\circ} 25^{\prime}$ ) is situated in the southeastern Baiquan County, Heilongjiang Province, China (Fig. 1). The reservoir was constructed in 1967 with storage capacity of $103 \times 10^{4} \mathrm{~m}^{3}$ for irrigation. The irrigation period extends from May to August. Although the water level is lowered during irritation period, the sediments are rarely exposed. The overall morphology of the catchment is characterized by long slopes and gentle gradient of ca. $4 \%$. The elevation of the catchment ranges from 200 to $270 \mathrm{~m}$.

The climate is semihumid and continental with a long and cold winter. Annual mean temperature is $1.28^{\circ} \mathrm{C}$, and mean January and July temperatures are $-22.6^{\circ} \mathrm{C}$ and $37.8^{\circ} \mathrm{C}$, respectively. Mean annual precipitation is $475 \mathrm{~mm}$. The major land uses in the catchment are crops (77\%), grassland (12\%), scrub (7\%), forest (2\%), and residential (2\%) (Fig. 1). The main crops are soybean (Glycine $\max (\mathrm{L}$.$) Merr.) and corn (Zea mays L.).$

The dominant soil association is classified as silty clay loam Mollisols and Phaeozem. The parent materials are Quaternary lacustrine and fluvial sand beds or loess sediments that lie below these soils (Wei et al., 2008).

\subsection{Soil sampling}

To maintain the dam, the reservoir was drained during 2011-2013. A pit was dug at its central part, a site usually used for collecting sediment core in a reservoir or other type of water body in literatures (e.g., Townsend and Seen, 2012; Lin et al., 2012), in September, 2013, and a $120 \mathrm{~cm}$ sedimentary column was collected along the edge of the pit. The column was locally subsampled at $2.4-\mathrm{cm}$ interval using an iron ring. The ring is $2.4-\mathrm{cm}$ high with a $10.5 \mathrm{~cm}$ diameter.

Each individual sample from the potential sediment source areas was a composite of 10 subsamples collected within an approximate $10-\mathrm{m}$ radius. For the (un) cultivated lands, soil samples were collected from $0-2 \mathrm{~cm}$ topsoils with a soil scraper. In the gully/ channel banks, the freshly-eroded scars were selected as the sampling points. In total, 180 and 90 samples were collected from cultivated and uncultivated lands, and 140 samples were collected from gully/channel areas where bank erosion and failure were active.

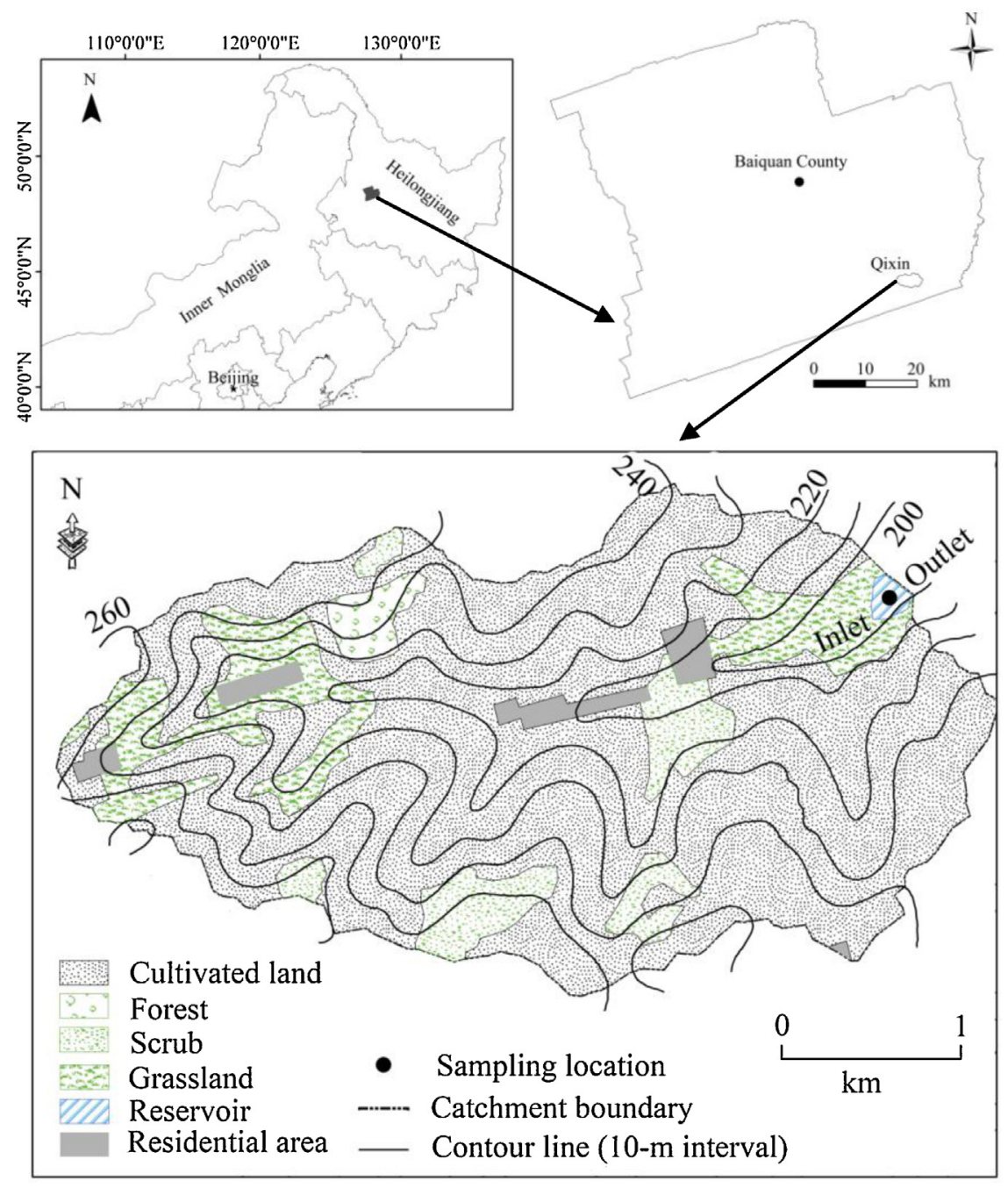

Fig. 1. Land use characteristics in the dam-controlled Qixin catchment and the sampling location within the reservoir. 


\subsection{Laboratory analysis}

All the samples were air-dried, weighted, and divided into two parts, one passing through a $2-\mathrm{mm}$ sieve for analyzing sediment particle size and radionuclide activities, and the other passing through a $0.1-\mathrm{mm}$ sieve for measuring soil organic carbon (SOC) content. Sediment size parameter was analyzed with a Mastersizer 2000 laser. The ${ }^{137}$ Cs activity of the samples was measured by a hyper-pure coaxial Ge detector linked to a multichannel analyzer, detected at $662 \mathrm{keV}$ peak with counting time over 80,000 s. The samples used for ${ }^{210} \mathrm{~Pb}_{\mathrm{ex}}$ analysis were firstly sealed in containers to achieve equilibrium between ${ }^{226} \mathrm{Ra}$ and its daughter ${ }^{222} \mathrm{Rn}$. The ${ }^{210} \mathrm{~Pb}_{\text {ex }}$ activity was then obtained by subtracting the ${ }^{210} \mathrm{~Pb}_{\text {sup }}$ concentration from the total activity. Total ${ }^{210} \mathrm{~Pb}_{\mathrm{ex}}$ activity was measured at $46.5 \mathrm{keV}$, and ${ }^{210} \mathrm{~Pb}_{\text {sup }}$ at $609.3 \mathrm{keV}$. SOC concentration was measured using a wet combustion method (Nelson and Sommers, 1996).

\subsection{Formula description}

Around $77 \%$ of the catchment is cultivated, and gully erosion cannot be neglected in the study catchment. Therefore, the sediment sources were broadly divided into three categories: cultivated lands, uncultivated lands and subsoil material from gully/channel banks. Radioactivities of the accumulated sediment from the three sediment sources are anticipated to be different, and a simple model that has been successfully used in literatures (e.g., Wallbrink et al., 1998; Zhang et al., 2004) was employed to determine the relative contributions of the three potential sediment sources to the sediment deposit.

$\mathrm{AC}_{\mathrm{u}}+\mathrm{BC}_{\mathrm{c}}+\mathrm{CC}_{\mathrm{b}}=\mathrm{C}_{\mathrm{s}}$

$\mathrm{AP}_{\mathrm{u}}+\mathrm{BP}_{\mathrm{c}}+\mathrm{CP}_{\mathrm{b}}=\mathrm{P}_{\mathrm{s}}$

$\mathrm{A}+\mathrm{B}+\mathrm{C}=1$

where $\mathrm{A}, \mathrm{B}$, and $\mathrm{C}$ represent the relative contributions from uncultivated lands, cultivated lands, and gully/channel sources to the deposited seidment, respectively. $\mathrm{C}_{\mathrm{u}}, \mathrm{C}_{\mathrm{c}}, \mathrm{C}_{\mathrm{b}}$ and $\mathrm{P}_{\mathrm{u}}, \mathrm{P}_{\mathrm{c}}, \mathrm{P}_{\mathrm{b}}$ represent the activities of ${ }^{137} \mathrm{Cs}$ and ${ }^{210} \mathrm{~Pb}_{\mathrm{ex}}$ from uncultivated lands, cultivated lands, and gully/channel banks, and $C_{s}$ and $P_{s}$ represent the respective total activities of ${ }^{137} \mathrm{Cs}$ and ${ }^{210} \mathrm{~Pb}_{\mathrm{ex}}$ of the deposited sediment.

\subsection{Rainfall erosivity}

The daily rainfall amount was collected from Baiquan county Meteorology Bureau. Annual rainfall erosivity (R) was estimated using the developed model by Zhang et al. (2002b):

$$
\mathrm{M}_{\mathrm{i}}=\alpha \sum_{\mathrm{j}=1}^{\mathrm{k}}\left(\mathrm{D}_{\mathrm{j}}\right)^{\beta}
$$

where $M_{i}$ is the half-month R-factor ( $M J m^{\prime} h^{-1} h^{-1} \mathrm{yr}^{-1}$ ), and $D_{j}$ is the erosive rainfall for day $\mathrm{j}$ in one half-month. $\mathrm{D}_{\mathrm{j}}$ is equal to the actual rainfall when it is greater than $12.7 \mathrm{~mm}$. Otherwise $D_{j}$ is equal to zero. $\mathrm{K}$ is the number of days in the half-month. $\alpha$ and $\beta$ are empirical parameters determined by the following regression:

$\beta=0.8363+\frac{18.144}{\overline{\mathrm{P}}_{\mathrm{d} 12}}+\frac{24.455}{\overline{\mathrm{P}}_{\mathrm{y} 12}}$

$\alpha=21.586 \beta^{-1.7891}$

where $\overline{\mathrm{P}}_{\mathrm{d} 12}$ and $\overline{\mathrm{P}}_{\mathrm{y} 12}$ are the average daily and yearly rainfall amounts larger than $12.7 \mathrm{~mm}$ in value for each rainfall event.

\section{Results}

\subsection{Radioactivities, SOC concentration and soil texture}

The average radioactivities, SOC concentration, and median particle size $\left(D_{50}\right)$ from the three potential sediment sources are given in Table 1. The soils from uncultivated lands had the highest radioactivities averaging $8.86 \mathrm{~Bq} \mathrm{~kg}^{-1}$ and $208.6 \mathrm{~Bq} \mathrm{~kg}^{-1}$ with standard deviations of $2.45 \mathrm{~Bq} \mathrm{~kg}^{-1}$ and $85.63 \mathrm{~Bq} \mathrm{~kg}^{-1}$ for ${ }^{137} \mathrm{Cs}$ and ${ }^{210} \mathrm{~Pb}_{\text {ex }}$, respectively. Least significant difference (LSD) indicated that the radioactivities in soils from cultivated lands were significantly lower than those from the uncultivated soils $(P<0.05$; Table 1$)$. The radioactivities from gully/channel banks were the lowest with mean values and standard deviations of $0.30 \mathrm{~Bq} \mathrm{~kg}^{-1}$ and $0.28 \mathrm{~Bq} \mathrm{~kg}^{-1}$ for ${ }^{137} \mathrm{Cs}$ and $7.50 \mathrm{~Bq} \mathrm{~kg}^{-1}$ and $2.47 \mathrm{~Bq} \mathrm{~kg}^{-1}$ for ${ }^{210} \mathrm{~Pb}_{\mathrm{ex}}$, respectively.

Uncultivated soils had the highest SOC concentration of $32.35 \mathrm{~g} \mathrm{~kg}^{-1}$ and the largest $D_{50}$ of $21.97 \mathrm{um}$, while the soils from gully/channel banks had the lowest SOC value of $9.70 \mathrm{~g} \mathrm{~kg}^{-1}$ and the smallest $D_{50}$ of $13.72 \mathrm{um}$. Cultivated soils had the median SOC concentration and $\mathrm{D}_{50}$ of $16.76 \mathrm{um}$. The SOC concentrations in uncultivated soils were significantly higher $(P<0.05$; Table 1$)$ than those from cultivated lands and gully/channel banks.

\subsection{Description of the sediment core}

The profile distributions of the radioactivities, SOC concentration and $\mathrm{D}_{50}$ are shown in Fig. 2. The ${ }^{137} \mathrm{Cs}$ activity presented irregular changes with increasing depth. Larger ${ }^{137} \mathrm{Cs}$ activities occurred at the depths of 2.4, 36, 64.8 and $115.2 \mathrm{~cm}$ and the smallest activity at ca. $40 \mathrm{~cm}$ depth. The reservoir was built in 1967 , after the primary period of ${ }^{137} \mathrm{Cs}$ deposition from the atmosphere. Therefore, the sampled sediments did not contain the peak activity of ${ }^{137} \mathrm{Cs}$ occurring in 1963, and it is difficult to determine the key year from the ${ }^{137} \mathrm{Cs}$ profile.

Table 1

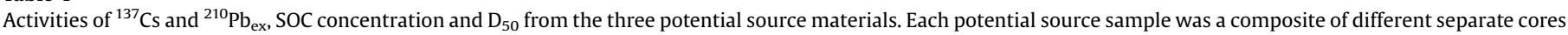
in the study catchment.

\begin{tabular}{|c|c|c|c|c|}
\hline & & Cultivated land & Uncultivated land & Gully sediment \\
\hline \multirow[t]{2}{*}{${ }^{137} \mathrm{Cs}$} & $\mathrm{n}$ & 180 & 90 & 140 \\
\hline & Mean + S.E. $\left(\mathrm{Bq} \mathrm{kg}^{-1}\right)$ & $2.05 \mathrm{a}(1.03)$ & $8.86 b(2.45)$ & $0.30 c(0.28)$ \\
\hline \multirow{2}{*}{${ }^{210} \mathrm{~Pb}_{\mathrm{ex}}$} & $\mathrm{n}$ & 180 & 90 & 140 \\
\hline & Mean + S.E. $\left(\mathrm{Bq} \mathrm{kg}^{-1}\right)$ & $95.0 \mathrm{a}(25.76)$ & $208.6 b(85.63)$ & $7.50 c(2.47)$ \\
\hline \multirow[t]{2}{*}{$\mathrm{SOC}$} & $\mathrm{n}$ & 180 & 90 & 140 \\
\hline & Mean + S.E. $\left(\mathrm{g} \mathrm{kg}^{-1}\right)$ & 20.15a (4.64) & $32.35 b(8.34)$ & $9.70 \mathrm{c}(3.83)$ \\
\hline \multirow[t]{2}{*}{$\mathrm{D}_{50}$} & $\mathrm{n}$ & 180 & 90 & 140 \\
\hline & Mean + S.E. (um) & $16.76 a(3.53)$ & $21.97 \mathrm{~b}(5.34)$ & $13.72 \mathrm{a}(2.52)$ \\
\hline
\end{tabular}

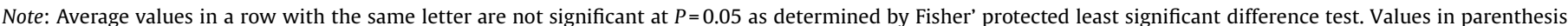
denote the standard deviation (S.E.). 

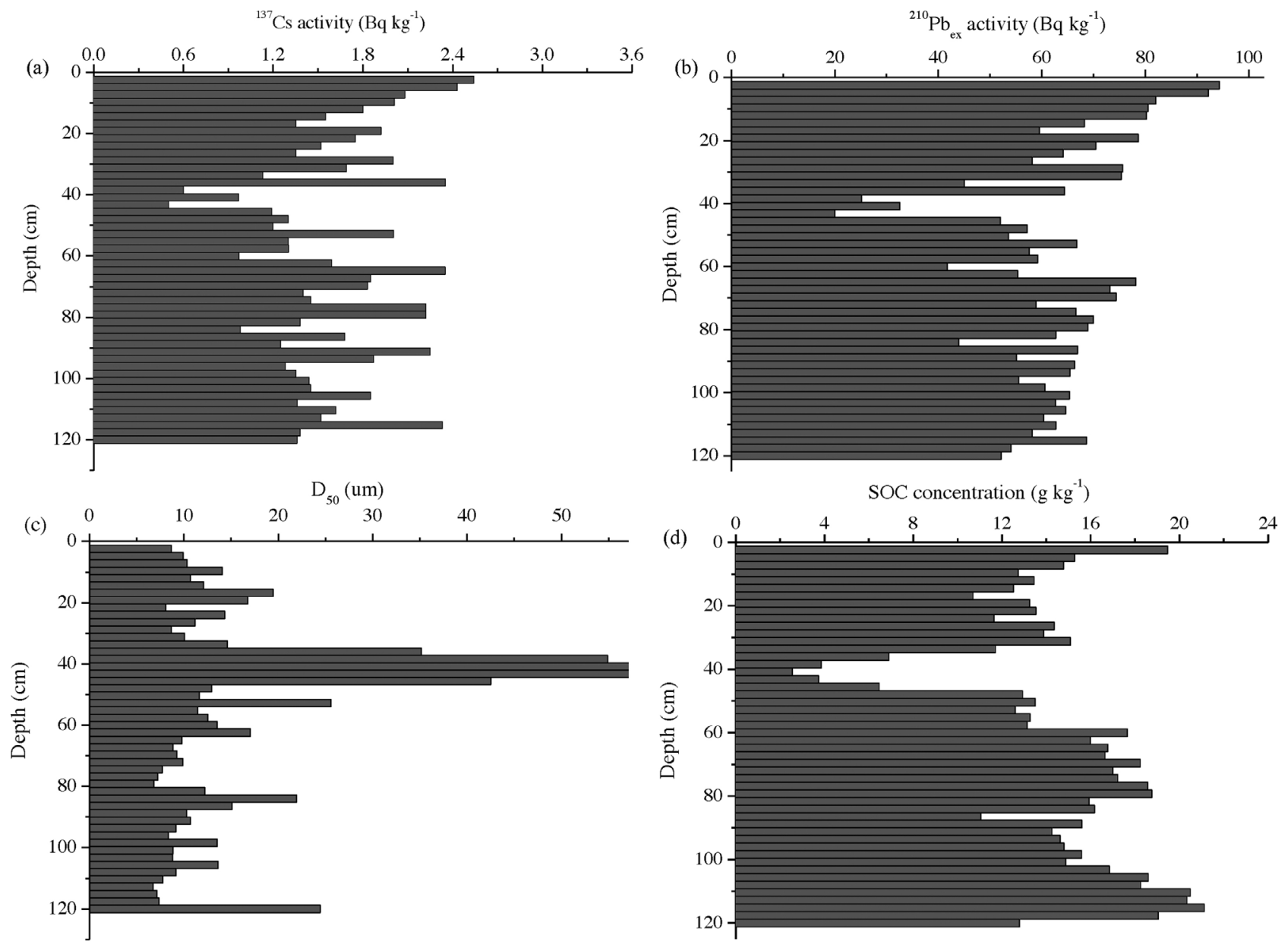

Fig. 2. Profile characteristics with increased sediment depth: (a) ${ }^{137} \mathrm{Cs}$ activity, (b) ${ }^{210} \mathrm{~Pb}_{\mathrm{ex}}$ activity, (c) $\mathrm{D}_{50}$ and (d) SOC.

The surface sediment had the highest ${ }^{210} \mathrm{~Pb}_{\mathrm{ex}}$ activity of $94.34 \mathrm{~Bq} \mathrm{~kg}^{-1}$. With increasing depth ${ }^{210} \mathrm{~Pb}_{\mathrm{ex}}$ activities showed an exponential decreasing trend, except for the very low ${ }^{210} \mathrm{~Pb}_{\text {ex }}$ activities (less than $40 \mathrm{~Bq} \mathrm{~kg}^{-1}$ ) occurring at $35-45 \mathrm{~cm}$ depth.

The values of $D_{50}$ varied greatly, with peaks appearing at different depths. The $\mathrm{D}_{50}$ was exceptional larger at $35-45 \mathrm{~cm}$ depth, followed at 16.8 and $84 \mathrm{~cm}$ depths. Lower $\mathrm{D}_{50}$ peaks occurred at ca. 21.6, 79 and $112 \mathrm{~cm}$ depths. The size of $\mathrm{D}_{50}$ reflects flood intensity, and then can to a certain extent help determine sediment source.

The SOC concentrations fluctuated greatly with increasing depth, ranging from 2.6 to $21.1 \mathrm{~g} \mathrm{~kg}^{-1}$. There are two SOC concentration peaks in the sediment core. The first peak of $19.5 \mathrm{~g} \mathrm{~kg}^{-1}$ at the core top could be caused by the increasing rate of SOC decomposition with depth under anoxic environment (Wei et al., 2005), and the second peak of $21.1 \mathrm{~g} \mathrm{~kg}^{-1}$ at $115.2 \mathrm{~cm}$ depth in the bottom is probably related to the originally higher SOC concentration of the black soils that were eroded, transport and finally deposited in the reservoir decades ago. Importantly, the lowest SOC concentration occurring at ca. $40 \mathrm{~cm}$ depth agrees with the lower radioactivities and larger $\mathrm{D}_{50}$ at this sampling depth.

\subsection{Relative contributions of the three potential sources}

Based on the radioactivities of the three potential sediment sources in Table 1 and of the sampled sediment layers in Fig. 2, Eqs. (1)-(3) were used and the relative sediment contributions from uncultivated lands, cultivated lands and gully/channel banks were obtained for each of the sediment layers (Fig. 3). On average, cultivated soils contributed a mean of $50.87 \%$ ranging from $12.22 \%$ to $80.84 \%$, uncultivated contributed a mean of $5.22 \%$ ranging from $0.01 \%$ to $21.49 \%$ and gully/channel banks gave a mean of $43.91 \%$ ranging from $15.15 \%$ to $86.91 \%$ (Table 2 ).

For the sediment layers, the deposited sediments from the gully/channels are comparable to those from the cultivated lands (Fig. 3). Especially for the layers 14-18 (from 33.6 to $43.2 \mathrm{~cm}$ in depth) and layer 25 (60 cm depth), the deposited sediments mainly came from gully/channel banks, ranging from 59.4\% in layer 14

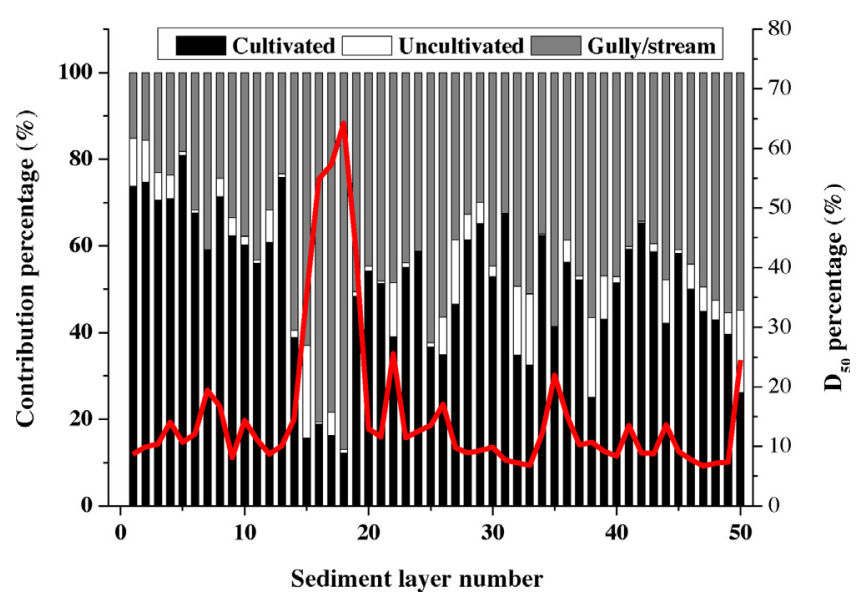

Fig. 3. Variation of sediment sources for each sediment layer for the sampled sediment core (50 sediment layers and $120 \mathrm{~cm}$ long in total). 
Table 2

Proportions of catchment sediment sources contributing to the sediments deposited within the reservoir.

\begin{tabular}{llll}
\hline & Cultivated & Uncultivated & Gully/channel banks \\
\hline Mean (\%) & 50.87 & 5.22 & 43.91 \\
Range (\%) & $12.22-80.84$ & $0.01-21.49$ & $15.15-86.91$ \\
S.E. (\%) & 16.478 & 5.72 & 15.32 \\
\hline
\end{tabular}

Note: S.E. represent standard error.

(33.6 $\mathrm{cm}$ in depth) to $86.9 \%$ in layer $18(43.2 \mathrm{~cm}$ in depth). The exceptionally high contributions from gully/channel banks could result from large flood event (Nahm et al., 2010).

\section{Discussion}

\subsection{Explanation of sediment contribution}

The black soil has experienced severe erosion over the last decades (Fang et al., 2012). Most of the eroded sediment is transported and impounded within reservoir. The deposited sediment thus could provide valuable information of soil erosion history (Nahm et al., 2010; Slimane et al., 2013).

On average, over half of the deposited sediment came from the cultivated lands (ca. 51\%; Table 2). This can be attributed to the large percentage of cultivated land (ca. 77\%; Fig. 1) covering the study catchment. In the study region, the erosion rate on the updown cultivated lands is up to $35 \mathrm{tha}^{-1} \mathrm{yr}^{-1}$ (Yu et al., 2012). However, because some conservation measures (e.g., terrace and contour cultivation; Wei, 2008) have been implemented since the 1960 s in the study catchment, the relative sediment contribution from cultivated lands to the reservoir sediment is less than those in the Heshan Farmland of the black soil region (Fang et al., 2012), in the southwestern region (Zhang et al., 2004) and on the Chinese Loess Plateau (Yang and Xu, 2010).

Uncultivated lands have lower erosion intensity than the other two sediment source areas. The erosion rates in uncultivated lands such as forest- and grass-lands are much less than the cultivated lands (Erskine et al., 2002). Furthermore, uncultivated lands covered less percentage (ca. 23\%) of the study catchment. Therefore, the relative sediment contribution from uncultivated lands was much less than those from cultivated lands.

Gully and channel banks are important sediment source areas in the black region (Hu et al., 2007). The soils on steep banks and actively eroding head are easily eroded away by intermittent flow of water, during and immediately following heavy rains (Dong et al., 2013). The average contribution from gully/channel banks to the deposited sediment agreed with the studies by Poesen et al. (1996) in Europe, Dong et al. (2013) and Fang et al. (2012) in the black soil region, and lower than those on the Loess Plateau (Tang, 1993 ) and in southern China areas (DiCenzo and Luk 1997).

\subsection{Temporal changes of sediment source}

Large variations in radioactivities, SOC concentration and $D_{50}$ of the column profile might be attributed to varying sediment yield and the relative contributions from different sediment sources over the past decades (Fig. 3). Land use and climatic factors impact the contributions from the potential sediment source areas (RuizFerna'ndez et al., 2005; Li et al., 2003). However, the land use types of the catchment keep constant during the past decades. This means that the changes of sediment contribution could be attributed to temporal changes of precipitation.

A deep light-colored sediment layer was observed at $35-45 \mathrm{~cm}$ depth along the pit edge (Fig. 4). The color of the sediment layer is quite different from those at its upper and lower sediments, and

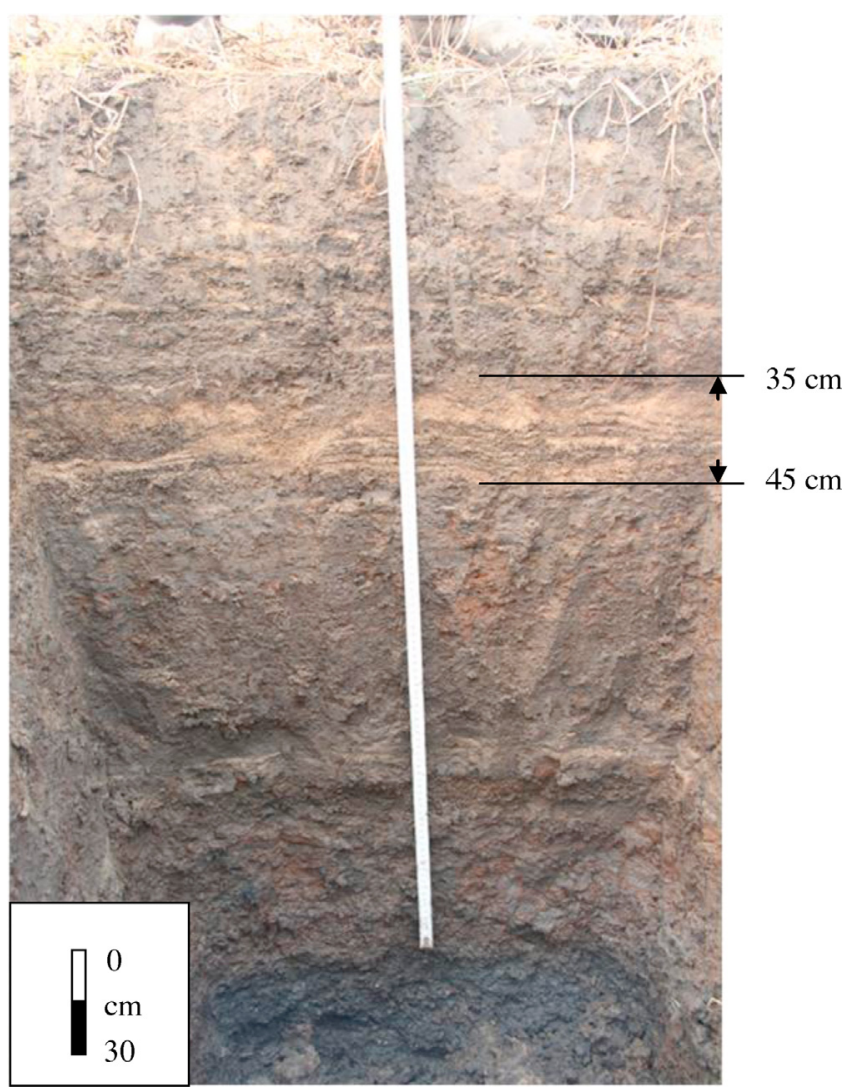

Fig. 4. A photo showing the profile of the sampled sediment core. The light-colored sediment layer appeared at $35-45 \mathrm{~cm}$ depth.

the $D_{50}$ of this sediment layer is exceptionally larger (Fig. 2), which could be induced by rainstorm (Rodbell et al., 1999; Noren et al., 2002; Nahm et al., 2010).

Under this consideration, rainfall information of the study region during 1970-2012 was explored. Fig. 5 shows that annual rainfall and rainfall erosivities varied greatly but had similar changing trend. In 1998, a heavy rainstorm occurred with the largest erosivity throughout the past decades. Literatures (Zhang et al., 2002a; Tang et al., 2012) demonstrated that the rainfall in 1998 was rare in recent 100 years. The resulted cataclysmic flood could induce severe gully erosion. In Heshan Farmland of the black

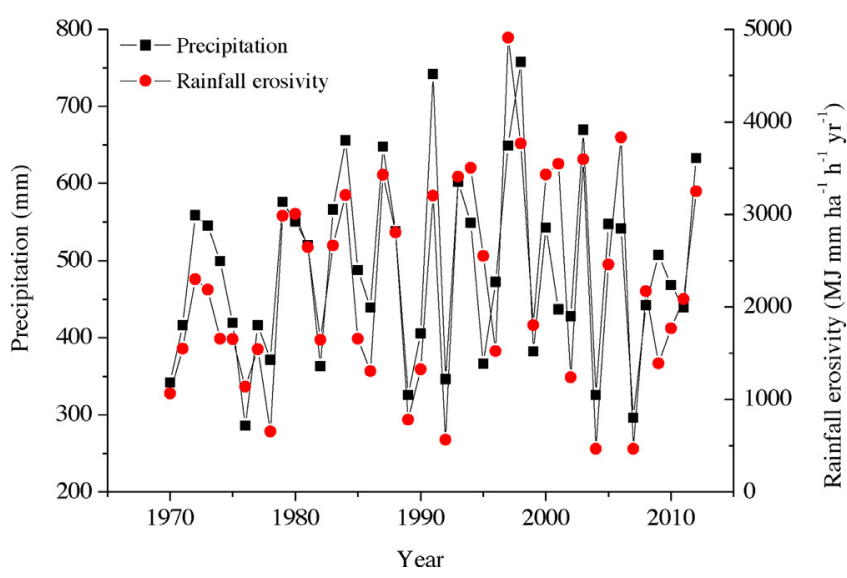

Fig. 5. Changes of annual rainfall amount and rainfall erosivity during 1970-2012. 
Table 3

Pearson correlation coefficient among radionuclide tracers, contributions of different sediment sources, median sediment particle $\left(\mathrm{D}_{50}\right)$ and SOC.

\begin{tabular}{|c|c|c|c|c|c|c|c|}
\hline & S1 (\%) & S2 (\%) & $\begin{array}{l}\text { S3 } \\
\text { (\%) }\end{array}$ & ${ }^{137} \mathrm{Cs}\left(\mathrm{Bq} \mathrm{kg}^{-1}\right)$ & ${ }^{210} \mathrm{~Pb}_{\mathrm{ex}}\left(\mathrm{Bq} \mathrm{kg}^{-1}\right)$ & $\mathrm{D}_{50}$ (um) & $\mathrm{SOC}\left(\mathrm{g} \mathrm{kg}^{-1}\right)$ \\
\hline S1 & 1 & & & & & & \\
\hline S2 & $-0.415^{*}$ & 1 & & & & & \\
\hline S3 & $-0.941^{* *}$ & 0.081 & 1 & & & & \\
\hline${ }^{137} \mathrm{Cs}$ & $0.281^{*}$ & $0.676^{* *}$ & $-0.560^{* *}$ & 1 & & & \\
\hline${ }^{210} \mathrm{~Pb}_{\mathrm{ex}}$ & $0.710^{* * *}$ & $0.316^{*}$ & $-0.896^{* *}$ & $0.869^{* * *}$ & 1 & & \\
\hline$D_{50}$ & $-0.609^{* *}$ & -0.024 & $0.676^{* * *}$ & $-0.494^{* *}$ & $-0.671^{* *}$ & 1 & \\
\hline SOC & $0.369^{* *}$ & 0.103 & $-0.443^{* *}$ & $0.437^{* *}$ & $0.504^{* *}$ & $-0.850^{* *}$ & 1 \\
\hline
\end{tabular}

" Indicates significant at $P=0.05$.

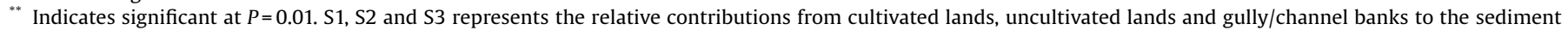
deposit of Qixin reservoir.

soil region in China, the retreat distance of one gully was 8.6 m only in one year (Hu et al., 2007). The samples from gully/channel banks contain lower radionuclide activities and SOC concentration (Table 1 ). The light-colored sand layer could be caused by the exceptionally large flood in 1998, when a large part of coarse soils were exported into the reservoir. The Pearson correlation coefficients among the three sediment sources, radionuclides, SOC and $\mathrm{D}_{50}$ indicated that sediment contributions from gully/ channel banks were positively correlated with $\mathrm{D}_{50}$ and negatively with SOC content and the two radionuclides' activities $(P=0.01$; Table 3). This analysis verified our inference from the sediment column.

${ }^{210} \mathrm{~Pb}_{\mathrm{ex}}$ dating models are often used to age sediment layers (Du and Walling, 2012). Additionally, the close relation between sediment size and rainfall information has also been used to date the sediment age in recent years (e.g., Nahm et al., 2010; Wang, 2013). In our previous paper (Fang and Sun, 2014), both ${ }^{210} \mathrm{~Pb}_{\mathrm{ex}}$ models and peak method were used to re-divide the sediment column into 26 layers each with a given year. In this way, the contributions from the three potential sediment sources and yearly rainfall information were connected with each other. Fig. 6 demonstrated that with increasing rainfall amount and rainfall erosivity, sediment contributions from gully/channel banks increased and from cultivated lands decreased while sediment from uncultivated lands varied little or slightly decreased. These changing patterns were in accordance with the studies by Kim et al. (2013) and Gourdin et al. (2014) that the relative contribution of uncultivated lands to reservoir sediment decreased while the bank contribution increased with an increase in maximum peak discharge. This can explain the exceptionally higher sediment contribution from gully/channel banks by the rainstorm in 1998 .

\section{Conclusions}

Sedimentation information in a reservoir was used in this study, and temporal variations of sediment source were disclosed using a simple mixing model with ${ }^{137} \mathrm{Cs}$ and ${ }^{210} \mathrm{~Pb}_{\mathrm{ex}}$. During the past decades, the mean relative contributions from cultivated lands, uncultivated lands and gully/channel banks to the sediment deposit of the reservoir were ca. $51 \%, 5 \%$ and $44 \%$. Their relative contributions to the reservoir deposit were significantly $(P=0.01)$ correlated with radioactivities, SOC and $\mathrm{D}_{50}$, and the temporal variations of sediment contribution depended on annual rainfall amount and rainfall erosivity. The relative contribution from cultivated lands decreased as annual rainfall and rainfall erosivity increased. Contribution from gully/channel banks increased as annual rainfall amount and rainfall erosivity increased. The contribution from uncultivated land was ca. $4 \%$ and did not change much over the past decades. Therefore, implementing effective soil conservation measurements in the cultivated lands and gully/channels and temporal and spatial preparation strategies for heavy rainstorms should be considered. Further studies of the application of physical models in combined with fieldwork investigations are required to better control soil erosion and to implement rational soil conservation measures.
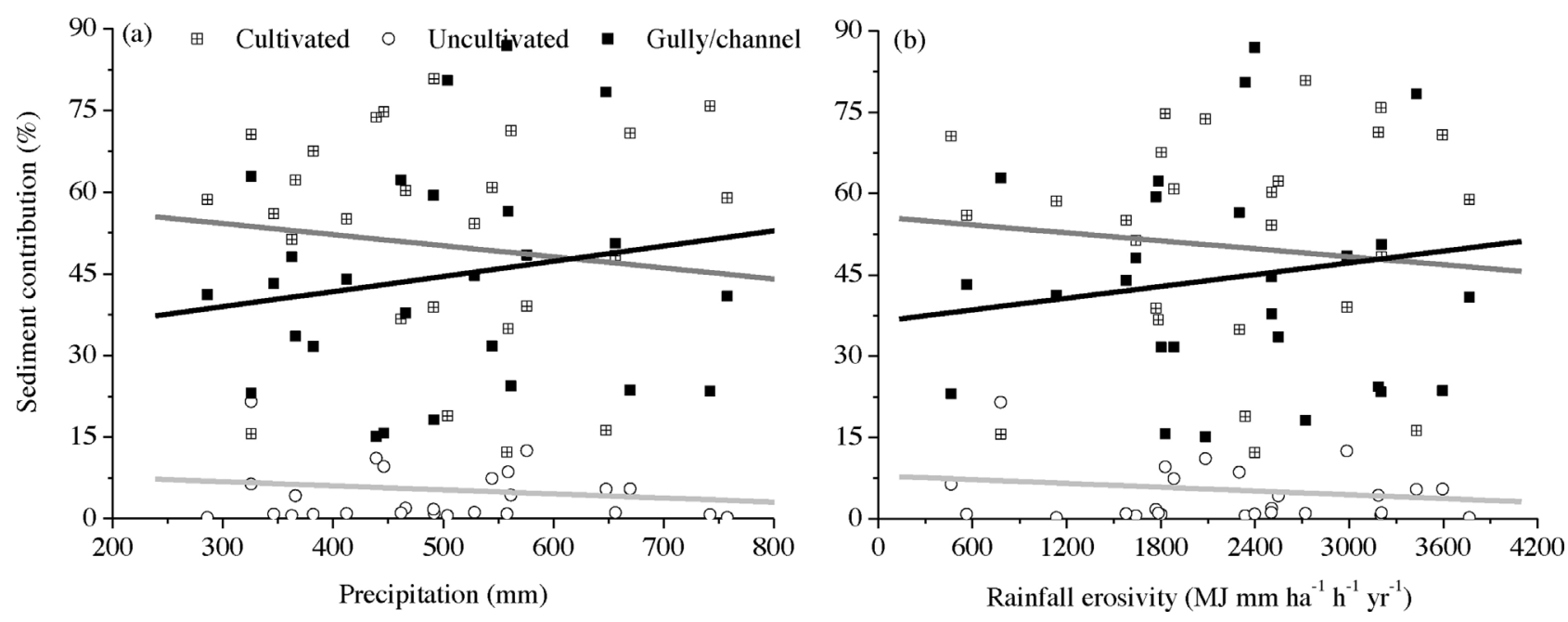

Fig. 6. Relationships between contributions from the three potential sediment sources and rainfall (a) and rainfall erosivity (b). 


\section{Acknowledgment}

This work was financially supported by projects of the National Natural Science Foundation of China (grant number 41271305).

\section{References}

Blake, W.H., Ficken, K.J., Taylor, P., Russell, M.A., Walling, D.E., 2012. Tracing cropspecific sediment sources in agricultural catchments. Geomorphology 139, 322-329.

DiCenzo, P.D., Luk, S.H., 1997. Gully erosion and sediment transport in a small subtropical catchment, South China. Catena 29, 161-176.

Dong, Y.F., Wu, Y.Q., Zhang, T.Y., Yang, W., Liu, B.Y., 2013. The sediment delivery ratio in a small catchment in the black soil region of Northeast China. Int. J. Sediment Res. 28, 111-117.

Du, P., Walling, D.E., 2012. Using ${ }^{210} \mathrm{~Pb}$ measurements to estimate sedimentation rates on river floodplains. J. Environ. Radioact. 103, 59-75.

Erskine, W.D., Mahmoudzadeh, A., Myers, C., 2002. Land use effects on sediment yields and soil loss rates in small basins of Triassic sandstone near Sydney, NSW Australia. Catena 49, 271-287.

Fang, H.Y., Sun L.Y., 2014. Determinations of sedimentation rates for a small catchment in Northeastern China. Land Degradation and Development, submitted.

Fang, H.Y., Sun, L.Y., Qi, D.L., Cai, Q.G., 2012. Using ${ }^{137}$ Cs technique to quantify soil erosion and deposition rates in an agricultural catchment in the typical black soil region, Northeast China. Geomorphology 169/170, 142-150.

Franz, C., Makeschin, F., Weib, H., Lorz, C., 2014. Sediments in urban river basins: identification of sediment sources within the Lago Paranoá catchment Brasilia DF, Brazil-using the fingerprint approach. Sci. Total Environ. 466-467, 513-523.

Gellis, A., Noe, G., 2013. Sediment source analysis in the Linganore Creek watershed, Maryland, USA, using the sediment fingerprinting approach: 2008 to 2010. J. Soils Sediments 13 (10), 1735-1753.

Gourdin, E., Evrard, O., Huon, S., Lefèvre, I., Ribolzi, O., Reyss, J.L., Sengtaheuanghoung, O., Ayrault, S., 2014. Suspended sediment dynamics in a Southeast Asian mountainous catchment: combining river monitoring and fallout radionuclide tracers. J. Hydrol. 519, 1811-1823.

Gruszowski, K.E., Foster, I.D.L., Lees, J.A., Charlesworth, S.M., 2003. Sediment sources and transport pathways in a rural catchment, Herefordshire, UK. Hydrol. Processes 17, 2665-2681.

Haddadchi, A., Nosrati, K., Ahmadi, F., 2014. Differences between the source contribution of bed material and suspended sediments in a mountainous agricultural catchment of western Iran. Catena 116, 105-113.

Haddadchi, A., Ryder, D.S., Evrard, O., Olley, J., 2013. Sediment fingerprinting in fluvial systems: review of tracers, sediment sources and mixing models. Int. J. Sediment Res. 28, 560-578.

Hu, G., Wu, Y.Q., Liu, B.Y., Yu, Z.T., You, Z.M., Zhang, Y.G., 2007. Short-term gully retreat rates over rolling hill areas in black soil of Northeast China. Catena 71 321-329.

Huisman, N.L.H., Karthikeyan, K.G., Lamba, J., Thompson, A.M., Peaslee, G., 2013. Quantification of seasonal sediment and phosphorus transport dynamics in an agricultural watershed using radiometric fingerprinting techniques. J. Soils Sediments 13 (10), 1724-1734.

Kim, J.K., Onda, Y.C., Yang, D.Y., Kim, M.S., 2013. Temporal variations of reservoir sediment sources in a small mountainous catchment in Korea. Earth Surf. Processes Landforms 38, 1380-1392.

Lamba, J., Karthikeyan, K.G., Thompson, A.M., 2015. Apportionment of suspended sediment sources in an agricultural watershed using sediment fingerprinting. Geoderma 239-240, 25-33.

Li, Y., Poesen, J., Yang, J.C., Fu, B., Zhang, J.H., 2003. Evaluating gully erosion using ${ }^{137} \mathrm{Cs}$ and ${ }^{210} \mathrm{~Pb} /{ }^{137} \mathrm{Cs}$ ratio in a reservoir catchment. Soil Tillage Res. 69, 107-115.

Lin, T., Qin, Y.W., Zheng, B.H., Li, Y.Y., Zhang, L., Guo, Z.G., 2012. Sediment record of polycyclic aromatic hydrocarbons in a reservoir in Northeast China. Environ. Pollut. 163, 256-260.

McKinley, R., Radcliffe, D., Mukundan, R., 2013. A streamlined approach for sediment source fingerprinting in a Southern Piedmont watershed, USA. J. Soils Sediments 13 (10), 1754-1769.
Nahm, W.H., Lee, G.H., Yang, D.Y., Kim, J.Y., Kashiwaya, K., Yamamoto, M., 2010. A 60 year record of rainfall from the sediments of Jinheung Pond, Jeongeup, Korea. J. Paleolimnol. 43, 489-498.

Nelson, D.W. Sommers, LE, 1996. Total carbon, organic carbon, and organic matter In: Bartel, J.M., Bigham, J.M. (Eds.), Methods of Soil Analysis. American Society of Agronomy, Madison, WI, pp. 961-1010.

Noren, A.J., Bierman, P.R., Steig, E.J., Lini, A., Southon, J., 2002. Millennial-scale storminess variability in the northeastern United States during the Holocene epoch. Nature 419, 821-824.

Peart, M.R., Walling, D.E., 1986. Fingerprinting Sediment Source: the Example of a Drainage Basin in Devon U. K., In Drainage Basin Sediment Delivery, 159. IAHS Publ., pp. 41-54.

Poesen, J.W., Vandaele, K., van Wesemael, B., 1996. Contribution of gully erosion to sediment production on cultivated lands and rangelands. Erosion and Sediment Yield: Global and Regional Perspectives (Proceedings of the Exeter Symposium, July 1996). IASH Publ. no. 236.

Rodbell, D.T., Seltzer, G.O., Anderson, D.M., Abbott, M.B., Enfield, D.B., Newman, J.H., 1999. An 15,000-year record of El Nino-driven alluviation in southwestern Ecuador. Science 283, 516-520.

Slimane, A.B., Raclot, D., Evrard, O., Sanaa, M., Lefevre, I., Ahmadi, M., Tounsi, M., Rumpel, C., Mammou, A.B., Bissonnais, Y.L., 2013. Fingerprinting sediment sources in the outlet reservoir of a hilly cultivated catchment in Tunisia. J. Soils Sediments 13, 801-815.

Tang, K., 1993. A field study on accelerated erosion due to cultivating forest and grassland. Soil Erosion, Runoff and Sediment production in the Yellow River Basin. China Science and Technology Press, Beijing, pp. 108-116.

Tang, J.M., Bu, K., Yang, J.C., Zhang, S.W., Chang, L.P., 2012. Multitemporal analysis of forest fragmentation in the upstream region of the Nenjiang River Basin, Northeast China. Ecol. Indic. 23, 597-607.

Townsend, A.T., Seen, A.J., 2012. Historical lead isotope record of a sediment core from the Derwent River (Tasmania, Australia): a multiple source environment. Sci. Total Environ. 424, 153-161.

Wallbrink, P.J., Murray, A.S., Olley, J.M., 1998. Determining sources and transit times of suspended sediment in the Murrumbidgee River, New South Wales, Australia, using fallout ${ }^{137} \mathrm{Cs}$ and ${ }^{210} \mathrm{~Pb}$. Water Resour. Res. 34 (4), 879-887.

Walling, D.E., 2005. Tracing suspended sediment sources in catchments and river systems. Sci. Total Environ. 344, 159-184.

Walling, D.E., Owens, P.N., Leeks, G.J.L., 1999. Fingerprinting suspended sediment sources in the catchment of the River Ouse, Yorkshire, UK. Hydrol. Processes 13 (7), 955-975.

Wang, Y.W., 2013. The Couple Relations Between Rainfall and Sediment Layers-an Example in Huangtuwa in Zizhou County. Shanxi University, Master thesis.

Wei J.B., 2008. Soil and Water Conservation Effects of Landscape Ecological Reconstruction in the Eroded Black Soil Region, Northeast China. Chinese Academy of Sciences, Beijing, China (Ph.D. Dissertation).

Wei, Z.Q., Liu, C.Q., Liang, X.B., Wang, F.S., Wang, S.F., 2005. Decomposition of soil organic matter and its relation to microorganism in the sediment of the Hongfeng Lake in Guizhou. Sci. Bull. 50, 1486-1489.

Yang, M.Y., Xu, L.J., 2010. Fingerprinting Suspended Sediment Sources in A Small Catchment on the Loess Plateau. J. Soil Water Conserv. 24 (2), 30-34.

Yu, H.Q., Li, Y., Nguyen, M.L., Funk, R., Liu, Q.G., Li, J.J., 2012. Fallout radionuclide based techniques for assessing the effectiveness of soil conservation measures in different eroded regions of China. J. Nucl. Agric. Sci. 26 (2), 340-347.

Zhang, J.Q., Zhou, C.H., Xu, K.Q., Watanabe, M., 2002a. Flood disaster monitoring and evaluation in China. Environ. Hazards 4, 33-43.

Zhang, W.B., Xie, Y., Liu, B.Y., 2002b. Rainfall erosivity estimation using daily rainfall amounts. Sci. Geogr. Sin. 22, 705-711.

Zhang, X.B., He, X.B., Wen, A.B., Walling, D.E., Feng, M.Y., Zhou, X., 2004. Study sediment source within a small catchment in Middle Sichuan Province: using 137Cs and 210Pbex two isotopes. Sci. Bull. 49 (15), 1537-1541.

Zhang, X.B., Li, S.L., Wang, C.H., Tan, W.P., Zhao, Q.C., Zhang, Y.Y., Yan, M.Q., Liu, Y.L., Jiang, J.J., 1989. Using ${ }^{137}$ Cs tracer to study the sediment source from a small catchment on the Loess Plateau. Chin. Sci. Bull. 3, 210-213. 